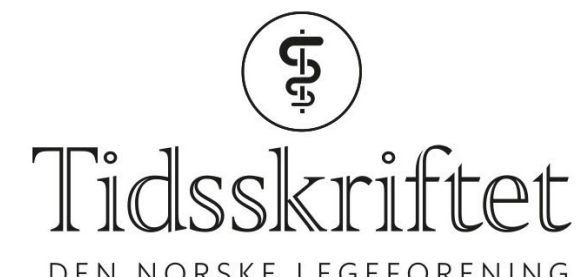

DEN NORSKE LEGEFORENING

\title{
Regresjonsanalyse på norsk
}

ANMELDELSER

ARE HUGO PRIPP

Forsker, Oslo senter for biostatistikk og epidemiologi, Forskningsstøtte, Oslo universitetssykehus

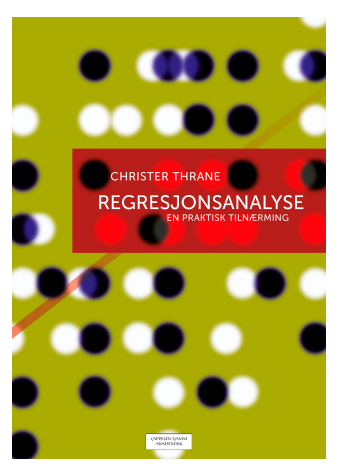

Christer Trane

Regresjonsanalyse

En praktisk tilnærming. 261 s, tab, ill. Oslo: Cappelen Damm, 2017. Pris NOK 399

ISBN 978-82-02-52914-7

Dette er en praktisk rettet lærebok basert på forfatterens bruk av regresjonsanalyse i forskning og på hans erfaringer som underviser. Intensjonen er å gjøre leserne i stand til å utføre, tolke og presentere regresjonsanalyser. Bruken av matematisk-statistisk terminologi og formler er bevisst holdt på et minimum. Målgruppen er studenter og forskere som trenger anvendt bruk av regresjonsanalyse i egne prosjekter. Datasettene og eksemplene er i hovedsakelig fra samfunnsfag og til dels helsefag (inkludert epidemiologi), men ikke fra klinisk medisin. Alle beregningene er utført med den statistiske programvaren Stata (www.stata.com).

Det er to hoveddeler: Basisemner i regresjonsanalyse og Videregående emner i regresjonsanalyse. Den første delen omhandler lineær regresjonsanalyse. Viktige temaer som regresjonsanalyse med en eller flere uavhengige variabler, analyse med kontinuerlige eller kategoriske uavhengige variabler, signifikanstesting og konfidensintervaller, de viktigste statistiske forutsetningene ved regresjonsanalyse samt mer avanserte temaer som ikkelineære sammenhenger og interaksjon er beskrevet. Del 2 om videregående emner i regresjonsanalyse er nyttig, men nok best egnet for lesere med en viss kjennskap til statistikkfaget. Den beskriver logistisk regresjonsanalyse og relaterte metoder der den avhengige variabelen (utfallsvariabelen) er kategorisk. De mange eksemplene er til hjelp for å forklare disse forholdsvis kompliserte metodene. 
Det finnes mange lærebøker om regresjonsanalyse - på engelsk. I en tid med økende bruk av engelsk i både forskning og undervisning er det prisverdig at det skrives norske lærebøker. Det er viktig å vise at vitenskapelige metoder og forskning også formidles godt på norsk. En utfordring er likevel at begrepene ofte er definert på engelsk. Det blir derfor innblanding av engelske ord og uttrykk, noe som ikke er lett å unngå når man skriver om statistiske metoder.

Christer Thranes bok kan anbefales til alle som vil lære mer om anvendt regresjonsanalyse. Jeg tror man får best utbytte av den hvis man allerede har noe kjennskap til regresjonsanalyse og bruk av den statistiske programvaren Stata. Et forslag ved en revidert utgave er at kapitlene utvides med noe mer teori og statistisk metode som supplement.

Publisert:30. oktober 2017. Tidsskr Nor Legeforen. DOI:10.4045/tidsskr.17.0682

(C) Tidsskrift for Den norske legeforening 2020. Lastet ned fra tidsskriftet.no 